\title{
Foreign Intelligence and Pharmaceutical Industry in Poland. Part 1
}

\section{Sikora}

For citation: Sikora M. Foreign Intelligence and Pharmaceutical Industry in Poland. Part 1. Vestnik of Saint Petersburg University. History, 2020, vol. 65, issue 4, pp. 1202-1217.

https://doi.org/10.21638/11701/spbu02.2020.411

In the 1960s, Polish society was still not affected by lifestyle diseases to such a large extent as in the developed countries of Western Europe. However, the statistics on cancer and cardiovascular diseases started to rise in the 1970s, along with dynamic economic development of Poland under communist party's secretary Edward Gierek. Meanwhile, the government of the People's Republic of Poland could not afford to invest simultaneously in all critical sectors of the economy. Particular priority was given to capital-intensive automotive and electronics industries as well as to traditional but important for Polish exports of raw materials (copper, coal). In the 1980s, as a result of the Cold War escalation along with the subsequent tightening of the strategic embargo by NATO states, and - finally - because of the gigantic foreign debt, the financial resources of Poland were reduced almost to zero. The lack of funds for research and development in the field of pharmacy and biotechnology was to be compensated for by an illegal transfer of know-how from the OECD area. Polish foreign intelligence services had already considerable experience in the field of purchasing technical documentation on the black market. In the 1970s, at least a dozen or so antibiotic manufacturing technologies were clandestinely obtained in the West and passed on to the Polish R\&D and industry. The article examines the involvement of Polish intelligence in the transfer of medicines, active substances and other pharmaceutical products (including medical equipment) to Poland. The "socially useful" function of communist secret services becomes a fascinating problem in this context. The article is partly based on the documents produced or collected by the Polish foreign in-

Miroslaw Sikora - PhD, Senior Specialist, Institute of National Remembrance, Office for History Research, Regional Branch, 102, ul. Józefowska, Katowice, 40-145 Poland; miroslaw.sikora@ipn.gov.pl; miroslaw.sikora@yandex.com

Мирослав Сикора - $\mathrm{PhD}$, ст. специалист, Институт национальной памяти, Управление исторических исследований (региональный филиал), Польша, 40-145, Катовице, ул. Жозефоувска, 102; miroslaw.sikora@ipn.gov.pl; miroslaw.sikora@yandex.com

This research was funded by National Science Center (NCN), Poland, Project Sonata, Edition 13, no. 2017/26/D/HS3/00250.

Исследование финансировалось Национальным научным центром (NCN), Польша, Project Sonata, издание 13, № 2017/26 / D / HS3 / 00250.

I would like to express my gratitude to Mark Kramer (Davis Center for Russian and Euroasian Studies) for his positive feedback and numerous comments which helped me to improve the scientific and linguistic quality of this article.

Я хотел бы выразить благодарность Марку Крамеру (Центр исследований России и Евразии Дэвиса) за его положительные отзывы и многочисленные комментарии, которые помогли мне улучшить научное и лингвистическое качество этой статьи.

(C) St. Petersburg State University, 2020 
telligence service in 1960-1990, which have been declassified and are now accessible to the public in the Archive of the Institute of National Remembrance.

Keywords: Poland, Cold War, Comecon, intelligence services, scientific espionage, pharmaceutical industry, history of technology.

\section{Внешняя разведка и фармацевтическая промышленность в Польше. Часть 1}

\section{М. Сикора}

Для цитирования: Sikora M. Foreign Intelligence and Pharmaceutical Industry in Poland. Part 1 // Вестник Санкт-Петербургского университета. История. 2020. Т.65. Вып. 4. С. 1202-1217. https://doi.org/10.21638/11701/spbu02.2020.411

В 1960-х гг. польское общество еще не было затронуто болезнями образа жизни в такой степени, как в развитых странах Западной Европы. Однако статистика рака и сердечно-сосудистых заболеваний начала расти в 1970-х гг. вместе с динамичным экономическим развитием Польши при первом секретаре коммунистической партии Эдварде Гереке. Правительство Польской Народной Республики не могло позволить себе одновременное инвестирование во все важнейшие секторы экономики. Особое внимание уделялось капиталоемкой автомобильной и электронной промышленности, а также традиционным, но важным для польского экспорта сырьевым отраслям (медь, уголь). В 1980-х гг. в результате эскалации холодной войны и последующего ужесточения стратегического эмбарго странами НАТО, а также из-за гигантского внешнего долга финансовые ресурсы Польши сократились практически до нуля. Недостаток средств для исследований и разработок в области фармации и биотехнологий должен был быть компенсирован незаконной передачей ноу-хау из зоны Организации экономического сотрудничества и развития. Польские службы внешней разведки уже имели значительный опыт в области закупки технической документации на черном рынке. В 1970-х гг. не менее десятка технологий производства антибиотиков были тайно получены на Западе и переданы польским научно-исследовательским и промышленным предприятиям. Статья содержит информацию о причастности польской разведки к переброске в Польшу лекарств, активных веществ и других фармацевтических продуктов (в том числе медицинского оборудования). В этом контексте общественно полезная функция коммунистических спецслужб становится интересной проблемой. Статья частично основана на документах архива Института национальной памяти, подготовленных или собранных польской службой внешней разведки в 1960-1990 гг., которые были рассекречены, а в настоящее время доступны для публичного использования.

Ключевые слова: Польша, холодная война, Совет экономической взаимопомощи (СЭВ), спецслужбы, научно-техническая разведка, фармацевтическая промышленность, история техники.

This article is a part of a broader project on the influence of intelligence on science and economy in communist Poland. It is being managed by the author within the Institute of National Remembrance (Instytut Pamięci Narodowej - IPN). Some works in the framework of the project have already been published in Polish as well as in foreign journals ${ }^{1}$. The former studies focused on describing and explaining the general modus

1 Sikora M.: 1) Wirtschaftliche Innovation durch Spionage. Forschung, Entwicklung und der Geheimdienst in der Volksrepublik Polen 1970-1990 // Jahrbücher für Geschichte Osteuropas. 2014. Bd. 62, no. 4. 
operandi of cooperation between Polish People's Republic (PPR) Ministry of Internal Affairs (Ministerstwo Spraw Wewnętrznych - MSW) and various other ministries and state authorities responsible for science, industry and finance.

The case study of Poland, presented here, is meant to shed some light on a unique phenomenon. This is namely the involvement of the intelligence agency in the sphere of healthcare. The analysis is mainly based on the documents of the Ministry of Health and Social Care (Ministerstwo Zdrowia i Opieki Społecznej - MZiOS) and the Ministry of Chemical [and Light] Industry (Ministerstwo Przemysłu Chemicznego [i Lekkiego] MPCh(iL)) of PPR. Moreover, it concerns the documents of Polish scientific-technical intelligence (Wywiad Naukowo-Techniczny - WNT) within MSW, which became declassified along with the establishment of the Archive of the Institute of National Remembrance (Archiwum Instytutu Pamięci Narodowej - AIPN; and its Regional Branch in Katowice) in 1998. Files of MZiOS and MPCh(iL) are stored in the Central Archive of Modern Records (Archiwum Akt Nowych - AAN) in Warsaw².

Scientific-technical intelligence during the Cold War was indeed a subject of numerous studies, both among western scholars and those from the eastern side of the Iron Curtain. Both were concerned with the activities of $\mathrm{CIA}^{3}$ as well as the KGB and its allies' operations ${ }^{4}$. However, little attention has been paid thus far on pharmacy or biotechnology, with most researches concentrating on dual-use components of microelectronics and IT, metallurgy of non-ferrous metals, the machine and automotive industry, aviation, shipbuilding, or pure military equipment ${ }^{5}$. This article aims to bridge that gap.

The spectrum of WNT's interests was wide, ranging from fertilizers to integrated circuits and to drilling machines. The actions of WNT were reformed at the beginning of the seventies ${ }^{6}$. They were examined from a general overview (that is on a broad, synthetic level of analysis) and were the subject of at least fragmentary studies ${ }^{7}$. This paper makes a classic deduction, looking at the WNT as a whole, and aims to reveal uncharted details (WNT in the area of pharmacy). The general thesis of this article is that the cooperation of intelligence with the science and industry of PPR, though within an authoritarian state,

S. 564-590; 2) The only globally successful "company" in Communist Poland? Scientific-technical intelligence and its role in technology transfer 1971-1989 // ICON Journal of the International Committee for the History of Technology. 2020. Vol. 25, no. 1. P. 12-38.

2 Compare: Sikora M. Terapia czarnorynkowa. Pomoc wywiadu MSW dla branży farmaceutycznej i biotechnologicznej w PRL 1960-1990 // Kwartalnik Historii Nauki i Techniki PAN. 2017. T.4. P. 65-104.

3 Maddrell P. Spying on Science: Western Intelligence in Divided Germany 1945-1961. Oxford, 2006; Richelson J. T. The Wizards of Langley, Inside CIA's Directorate of Science and Technology. Boulder, 2001.

${ }^{4}$ Macrakis K. Seduced by Secrets. Inside the Stasi's Spy-Tech World. Cambridge, 2008; Chertoprud S. V. Nauchno-technicheskaia razvedka ot Lenina do Gorbacheva. Moscow, 2002.

${ }^{5}$ Cain F. Computers and the Cold War: United States Restrictions on the Export of Computers to the Soviet Union and Communist China // Journal of Contemporary History. 2005. Vol.40, no. 1. P. 131-147; Bergien R. Programmieren mit dem Klassenfeind. Die Stasi, Siemens und der Transfer von EDV-Wissen im Kalten Krieg // Vierteljahreshefte für Zeitgeschichte. 2019. Bd. 67, no. 1. P. 1-30.

${ }^{6}$ Studies on previous years of WNT are still at the stage of research postulates. Now one may ascertain that the period of two first decades of intelligence actions is slightly represented in records transferred to IPN after 1998. Most of them were probably made defective according to the procedures of keeping archive records in the times of PPR.

7 Paczkowski A. Rezydentura wywiadu MSW w Ministerstwie Przemysłu Maszynowego (1971-1983) // "Budujemy socjalizm...." Materiały pokonferencyjne. Wroclaw, 2010. P.47-60; Bagieński W. Wkład wywiadu gospodarczego w rozwój przemysłowy w dekadzie Edwarda Gierka // Dekada Gierka. Wnioski dla obecnego okresu modernizacji Polski. Warsaw, 2011. P. 57-71. 
was in selected areas helpful to the public interest. In order to prove this notion, the article examines a sample in the form of intelligence operations in the area of biochemistry and pharmacy. There are three reasons for choosing that area of STI activity (i. e. pharmacy) for a detailed analysis. First, healthcare is associated more with the civilian sector than any other branch of science and industry. The military in PPR did not have much interest in healthcare. Obviously, similarly to any field of R\&D, pharmacology has a number of military aspects, such as supplying soldiers with psychoactive remedies and increasing their fighting skills; not to mention the use of biotechnology in construction of biological weapons. However, in comparison with electronics, computer science, metallurgy, or the machine industry, the field selected has the fewest military components. It also does not involve the complexity of restrictions imposed by the Coordinating Committee for Multilateral Export Controls (CoCom $)^{9}$. Secondly, from the exchange of intelligence information between the scientific-technical intelligences (STI) of PPR and the USSR in the eighties, one may conclude that both countries were firstly primarily interested in the problems of biochemistry, especially in pharmacological applications, which apart from IT topics, make up a vital part of shared data ${ }^{10}$. The third reason for selecting pharmacy as the focus of research is that compared to other areas of espionage, records show that this branch of spying was financially the most profitable. It was also well documented. In this respect, there is a chance of making a quantitative assessment of WNT's input in the medical-pharmaceutical branch of PPR.

Besides the introduction and conclusion, this article consists of three chapters. The first one focuses on the structure of the Polish STI. The second one presents the background of institutional interference by intelligence in the pharmaceutical and R\&D industries. The third, which makes the second part of this article (Issue 1/2021), presents the assets and explains the modus operandi of STI. Furthermore it discusses objectives and financial results of the clandestine operations.

Scientific-Technical Intelligence in the Polish People's Republic. Intelligence partnerships of the countries of the Warsaw Pact, including PPR intelligence delivered to their respective governments and to the "government of governments" in Moscow vital information and analysis on NATO countries and unengaged countries. However, intelligence wasn't confined to the evaluation of enemies' military potential, arrangement of military units, or warfare technologies remaining in use and development. It was also capturing files and records on technological solutions, technical blueprints, chemical formulas, or material samples for economy and society.

PPR intelligence, and especially its civil branch known as Department I of the Ministry of Internal Affairs (MSW), was used as a very sophisticated think-tank for research and development. Moreover, STI was a tool of clandestine acquisition of technologies that either underwent embargo restrictions or were simply too expensive for legal purchase

${ }^{8}$ On the subject of functions of biotechnology in the area of military affairs, see: Kamieński $€$. Technologia i wojna przyszłości. Wokół nuklearnej i informacyjnej rewolucji w sprawach wojskowych. Krakow, 2009. P. 343-363.

${ }_{9}$ Coordinating Committee for Multilateral Export Controls. On the subject of genesis, function and effectiveness of that organization, see: Mastanduno M. Economic Containment: CoCom and the Politics of East-West Trade. Ithaca; New York, 1992.

${ }^{10}$ For more, see: Sikora M. Intelligence-interchange in the area of Science and Technology between Poland and Soviet Union 1986-1990 // Technology in Times of Transition. 41 ICOHTEC Symposium 2014. Brasov, 2014. P. 97-106. 
in form of licensing agreement with the capitalist states. With the passing of years, several experimental reorganizations inside Department I took place. As a result, specialized units and more flexible teams were established, which divided the whole of science and industry among themselves. Several hundreds of specialist institutes including those that belonged to the Polish Academy of Sciences (Polska Akademia Nauk - PAN), construction and design offices as well as R\&D centers (Ośrodek Badawczo-Rozwojowy - OBR) were infiltrated by undercover officers or recruited sources (collaborators, consultants and agents $)^{11}$. It is estimated that about 30-40 officers were simultaneously employed full time overtly or secretly in STI in the country and abroad in the sixties and seventies, STI-Manpower then started to increase year by year along with reescalation of the Cold War tensions at the turn of seventies and eighties reaching its peak by the late eighties with 130 officers $^{12}$.

Both dimensions of "research," the official and the unofficial, did not rival but complemented each other. It is impossible to thoroughly discuss the history of Polish science in the years of PPR without taking into consideration the unofficial sphere. Its contribution to the improvement of society's life was rather significant, though it should be underlined that even during its largest triumphs, the WNT was barely supplementing Polish $\mathrm{R} \& \mathrm{D}$ potential in pharmacy and not substituting it.

Scientific-technical intelligence of PPR organized itself along with the creation of the Ministry of Public Security in 1945, which was renamed in 1956 the Ministry of Internal Affairs. STI worked for a dozen or so years rather in isolation from the legal sphere of science and industry in PPR, and was focused on general extension of its network of agents and contacting channels abroad. Throughout the fifties relations between the overt and secret spheres of R\&D became more intense. This was because a disguised representation of WNT called the Committee of Economic and Scientific-Technical Cooperation with Abroad was established within the governmental institution ${ }^{13}$. The committee coordinated general intelligence gathering by searching out and indicating interest (for the WNT) in foreign companies/institutions. It established official contact with those organizations. At the beginning of the sixties, the WNT still employed only eighteen officers in its HQ; another eight took posts in cover institutions in the homeland (so called "second line", while the "first line" was HQ) and the same number went to Polish embassies abroad. In 1961, WNT (until that time known as Division VI Department I) Chief Lieutenant Colonel Michał Goleniewski deserted and revealed his knowledge to the CIA. The work of that department broke down for obvious reasons (exposure of its sources and loss of commu-

${ }^{11}$ Half a million engineers and technicians were employed in PPR's R\&D in the apex period of seventies. Bogal S. Ochrona myśli naukowo-technicznej w PRL [Handbook for Ministry of Interior's higher schools and training courses]. Warsaw, 1974 // Archive of the Institute of National Remembrance, Branch in Katowice (AIPN Ka), sign. 0216/189. P. 12.

12 Staff statistics of Department I covering 1963, 1967, 1970, 1973, 1977, 1981, 1986, 1989 // Archive of the Institute of National Remembrance [Warsaw] (AIPN), sign. 3484/210, 213, 215, 216, 217, 219, 221, $223,115,116$. During the years 1975-1990 the entire Department I MSW employed a total number of about a thousand workers, holding covert job positions (about 2/5) and secret job positions (about 3/5) in and outside of the country. For detailed data, see: Aparat bezpieczeństwa w Polsce. Kadra kierownicza: w 3 t. T. 3: 1975-1990. Warsaw, 2008. P. 40.

${ }^{13}$ For the history of the structural reorganizations of Department I, taking into account WNTcomplex in the early period, see: Wybrane zagadnienia $\mathrm{z}$ historii wywiadu MSW [Handbook for Ministry of Interior's higher schools and training courses] Warsaw 1987 // AIPN, sign. 02271/16. P.10-11, 33; Bagieński W. Wywiad cywilny Polski Ludowej w latach 1945-1961. T. 1-2. Warsaw, 2017. 
nication channels in western countries $)^{14}$. The assignment to rebuild the spy system and to reconfigure WNT tasks (since 1961 as Division VII) was to be undertaken by one of its next chiefs, Adam Krzysztoporski, the future vice minister of interior affairs. During his term in office, the "second line" was extended by placing more employees in cover institutions. The obvious effect of such a move was tightening contacts between intelligence and industry, though its quality still left much to be desired. According to some former intelligence workers, due to inefficient clerks at the ministry and a lack of qualified workers in $\mathrm{R} \& \mathrm{D}$, there was an insufficient implementation of technologies acquired in the West by Polish Intelligence in the sixties ${ }^{15}$.

The truly synergistic link between potential and instruments of intelligence on the one hand and institutions managing industry and technological implementations on the other came only after the actions were undertaken in Edward Gierek's administration (first secretary of Polish United Workers' Party/PZPR from 1970 to 1980). In the summer of 1973, the first officers graduated from the newly established Center for Training of the Intelligence Staff (OKKW) in Stare Kiejkuty. At the same time, one of the most revolutionary changes in the history of the scientific-technical section of Polish intelligence occured. The so-called Directorate VII was brought to life and replaced Division VII. It meant a break with the former structure of Department I, which was composed of Divisions. The new status of the "Directorate" placed scientific-technical intelligence somewhat above two mighty segments which still remained dispersed. The first one resembled a complex network of divisions working in accord with key political territories, thus being responsible for operations directed against the FRG, USA, Vatican etc. The second one covered the auxiliary complex (counterespionage, illegal intelligence, inspirations and black operations). For all of those mentioned, the functions of intelligence remained organized within the individual divisions subordinated directly to the Chief of Department I, while Directorate VII itself consisted of five divisions: first, the organization of STI's ties to industry; second, biotechnology, pharmacy and chemistry; third, microelectronics, IT and automation of industry; fourth, power engineering, heavy and machine industry; and fifth, economy, finance and natural resources. The question then arises as to what the reasons for the organizational promotion of the scientific-technical complex were.

There was no other reason for the reorganization of 1973 than to raise the standard of efficiency for processing intelligence information from the disciplines of science and industry. It might also have been concerned with isolating workers in that department from others in order to avoid disturbance when a desertion of one of the officers of the political complex or auxiliary complex occurred. However, it is still puzzling why similar actions with regard to those complexes had not been taken and why the complexes were not organized into directorates. Personal agendas might also have been involved, such as building a structure for its chief and at the same time giving him more power than that of his colleagues (bosses of divisions). The first scenario appears to be most convincing. Chief Brigadier General of Department I Józef Osek and the first director of Directorate VII Colonel Adam Krzysztoporski were trying to create a modern multidisciplinary center capable of accelerating the legal and illegal transfer of technologies in Poland. More-

14 For more on information revealed to the CIA and other services by Goleniewski, see: Pawlikowicz L. Tajny Front Zimnej Wojny. Uciekinierzy z polskich służb specjalnych 1956-1964. Warsaw, 2004. P. $215-301$.

15 Siemiątkowski Z. Wywiad a władza. Wywiad cywilny w systemie sprawowania władzy politycznej PRL. Warsaw, 2009. P. 125-128. 
over, they aimed to support Polish commerce in the West ${ }^{16}$. Establishing Directorate VII in 1973 could be also regarded as copying a Soviet pattern, namely Directorate "T" set up within the intelligence branch (Pervoe glavnoe upravlenie) of the KGB in 1963 and reorganized in 1968. In order to support this hypothesis, it is possible to refer to the branch of STI (called Sektor für Wissenschaft und Technik) in East Germany which in 1971 was also reorganized into a semi-independent department within intelligence (Hauptverwaltung Aufklärung), consisting in turn of several divisions covering individual areas of technology, exactly as it was in Poland and the USSR ${ }^{17}$.

An important component of the newly formed system for aiding science and industry were the so-called external intelligence workers (also called "second line" workers). They were placed in teams of secret, full-time positions by intelligence forces in several ministries responsible for individual branches of industry (especially in those dealing with machine construction and microelectronics, heavy industry and energy, and chemistry and biotechnology), moreover in R\&D centers, scientific institutes and even ordinary plants. The next, somewhat frontal pillar, of STI were the staff intelligence workers, operating from Polish embassies and consulates in capitalist camp or employed in various joint venture companies selling Polish products, offering Polish consulting, or importing high-tech products from the West ${ }^{18}$. It was they who reached the bidders, mainly workers of western companies or research centers interested in exchanging their knowledge or copies of technical blueprints for $\operatorname{cash}^{19}$.

Structural and Functional Background of Pharmaceutical R\&D Interference with Intelligence. The most spectacular breakthrough in medicine was probably achieved in the fifties and the sixties. It particularly involved the development, manufacturing, and spread of antibiotics. Western civilization along with the Soviet Union defeated venereal diseases and tuberculosis, which had been a curse for centuries. However, those diseases were soon replaced in the statistics by the equally ruthless killers such as cardiovascular diseases, diabetes, and malignant tumors. They were emblematic of the highly developed and affluent societies of the second half of the twentieth century ${ }^{20}$.

Favorable circumstances for the pharmaceutical industry in the twentieth century emerged with the discovery of the so-called sulfonamides, i.e. first strong chemotherapy drugs, following successes in their use in treatment. By the end of the twenties, scientists discovered many interesting properties of penicillin and in the next decade positively verified them in clinical research, i.e. its ability to kill or block the development of surrounding germs. This was later classified as an antibiotic. At this point, a radical change was

16 Another important function, especially in the seventies, was an intelligence gathering on the Western European economic partners (Germany, France, Italy, and Great Britain). See, for example, cases concerning automotive industry crypt: "Torino," which referred to Fiat Company and "Karoca," which referred to Renault company // AIPN, sign. 01593/798, 01739/185.

17 Compare Macrakis K. Seduced by Secrets. P. 25-38; and Chertoprud S. V. Nauchno-technicheskaia razvedka... P. 562-619.

18 See: Zacharski M. Nazywam się Zacharski. Marian Zacharski. Wbrew regułom. Poznan, 2009.

19 Another group of intelligence workers was comprised of the so-called illegals, that is officers who had false identity. See: Buthak W. Pion 'N' wywiadu cywilnego PRL. Ewolucja struktur, uwarunkowania organizacyjno-prawne i przykłady operacji tzw. wywiadu nielegalnego w strukturach Ministerstwa Bezpieczeństwa Publicznego, Komitetu ds. Bezpieczeństwa Publicznego i Ministerstwa Spraw Wewnętrznych // Studia nad wywiadem i kontrwywiadem Polski w XX wieku: w 2 t. T. 1. Szczecin, 2012. P. 607-682.

20 Tubiana M. Nowotwory, trans. by L. Łuka-Lognone. Warsaw, 1995. P.7-10; Mukherjee S. Cesarz Wszech Chorób. Biografia raka. Gorlice, 2013. P.27, 72-73. 
made in research concerning bactericides and bacteriostatic agents. It was almost a magical way to defeat such diseases as pneumonia, scarlet fever, and diphtheria, which had often been deemed deadly until that time ${ }^{21}$. In the forties and fifties, the pharmacology and pharmaceutical industries were dominated by discoveries. The application of antibiotics, for example, streptomycin, was especially effective in fighting tuberculosis bacteria. Moreover, the research into antibiotics moved from Western Europe to the US, and especially to Japan, where a number of spectacular successes were achieved, for instance, improvement of erythromycin. The efforts culminated in the fifties with the elaboration on the technology to produce semisynthetic antibiotics. Another important discovery of the sixties was gentamicin, which was used in treating inflammation of sight organs and infections of bones, skin and soft tissues. In the second half of the twentieth century, there was also a dynamic growth in the development and trade of vaccines and vitamins ${ }^{22}$. A following significant breakthrough in medicine began with the discovery of the DNA structure by biochemists during the fifties, and the subsequent gradual reconstruction of human genetic code lasting for five decades ${ }^{23}$.

Medical and agricultural uses of biotechnology turned out to be, similarly the whole IT area, extraordinarily influential scientific disciplines and industrial branches in the second half of the twentieth century. Eric Hobsbawm concluded that "without genetics India and Indonesia could not have produced sufficient amounts of food for the rapidly growing population. At the end of the millennium, biotechnology became an important element both in agriculture and in medicine. In technologies of that kind it was essential that they were based on discoveries and theories distant from the world of average men, even those who lived in the most developed and refined countries", and further - "technology of dividing DNA, that is technology of exchanging and substituting genes coming from various species for the first time was acknowledged as useful in 1973. More or less 20 years later biotechnology was the main investment in medicine and agriculture" 24 . This fact was best reflected in the growth of yearly budgets of health ministries in those countries and also in costs paid by pharmaceutical super-companies for research. Nowadays, elaboration and introduction of medicine into the market is an investment of hundreds of thousands or even hundreds of millions USD ${ }^{25}$. The temptation to omit only some of the capital absorbing periods of implementation is thus obvious.

In the first two decades of PPR, thanks to antibiotics and protective vaccinations for children, Polish healthcare had time to manage the post war "plagues" of infectious diseases like measles, pertussis, scarlet fever, diphtheria, Heine-Medina disease, dysentery, typhoid fever, and tuberculosis. A radical decrease in the sickness rate was also noted in

21 Historia medycyny / ed. by T. Brzeziński. Warsaw, 1995. P. 307-311.

22 Ibid. P. 311-315; Historia farmacji / eds R. Rembieliński, B. Kuźnicka. Warsaw, 1987. P. 132-133.

23 In particular, mechanisms of copying (replication/recombination) of DNA were explained, thousands of human genes, consisting of three billion bases, were specified and about twenty - named, and also twenty kinds (in total several hundreds of thousands) of human proteins, coded as 64 so-called triplets of the informational ribonucleic acid mRNA were identified. For more details on history of biotechnology, see: History of Modern Biotechnology: in 2 vols / ed. by A. Fiechter. Vol. 1. New York, 2000.

${ }^{24}$ Hobsbawm E. Wiek skrajności. Spojrzenie na Krótkie Dwudzieste Stulecie. Warsaw, 1999. P.478, 480. There is an extensive scientific literature on contemporary application of biotechnology in agriculture. See, for instance: Hallam S. Biotechnology and Society. An introduction. Chicago; London, 2016.

25 Landes D. S. Bogactwo i nędza narodów. Dlaczego jedni są tak bogaci, a inni tak ubodzy, trans. by H. Jankowska. Warsaw, 2005. P. 30. - For more on R\&D spending in area of biotechnology, see: Pharmaceutical R\&D: Costs, Risks and Rewards. Washington, 1993. 
venereal diseases (syphilis and gonorrhea) ${ }^{26}$. Regardless of the poor state of the Polish socialist-type economy compared to western countries, in the seventies, Poles entered into the orbit of dangers which accompanied the societies of prosperity in highly developed countries ${ }^{27}$. The first place among those dangers were taken by circulatory system diseases, which were quickly followed by malignant tumors. According to the Central Office of Statistics (Główny Urząd Statystyczny - GUS) data, as of 1960, there were almost 30 thousand people falling ill with cancer, and ten years later, there were almost twice as many ${ }^{28}$. In 1985, heart-related illnesses were still the first in death statistics (50 percent), while tumors were responsible for almost 18 percent $^{29}$. The main method of treating tumors was, at that time, surgery aided by chemo and radiotherapy ${ }^{30}$.

Apart from the Ministry of Health and Social Care (MZiOS), the program for protection of health in Polish society involved the Ministry of Chemical Industry (since $1981-$ the Ministry of Chemical and Light Industry, MPCh[iL]). It can be confidently concluded that the latter department and its subordinated organs were involved into clandestine undertakings of intelligence to an incomparably larger degree than the administration subordinated to the minister of health. The Ministry of Chemical (and Light) Industry was also responsible for production of the majority of medicine made in Poland. In the second half of the sixties, national companies subordinated to it, covered 70 percent of Polish demand for medicine supplying the national market with 770 from almost 1700 positions (including 100 imported) placed in the medical registry. Even 600 out of the above mentioned 770 positions were produced in plants united within the Pharmaceutical Industry Association "Polfa" 11.

There was a fundamental division in the scope of scientific research between institutions of the health and chemistry departments. The institutions controlled by MZiOS were doing mainly basic research and working out modern medical apparatus as well as serums

${ }^{26}$ Ministry of Health and Social Care - Yearbook 1972, Warsaw 1973 // Central Archives of Modern Records, Warsaw (AAN), Ministerstwo Zdrowia i Opieki Społecznej (Ministry of Health and Social Care), sign. 19/688, introduction.

${ }^{27}$ Percentage of deaths caused by tumors and circulatory system diseases amounted in Poland to the similar level as in countries such as Norway, Finland, Portugal, or the USA, and it was lower than, for example, in Austria, France, Denmark, Sweden, FRG, or in Great Britain. Ministry of Health and Social Care - Statistical Bulletin 1985, Warsaw 1986 // AAN, Ministry of Health and Social Care, sign. 19/689, table No. 115.

${ }_{28}$ Ministry of Health and Social Care - Yearbook 1972, Warsaw 1973 // AAN, Ministry of Health and Social Care, sign. 19/688, tables No. 122 and 123.

29 In this year, due to circulatory system diseases 194,000 Poles died, whilst 68,000 died of cancer. Diseases of respiratory system and digestive system caused 33,000 deaths - a bit more than deaths from accidents, injuries, and poisonings (27,000). Ministry of Health and Social Care - Statistical Bulletin 1985, Warsaw 1986 // AAN, Ministry of Health and Social Care, sign. 19/689, table No. 8.

${ }^{30}$ Basic questions of the pharmacy department, 1973. June 22 // AAN, Ministry of Health and Social Care, sign. 15/15. P. 26.

31 Plants of Herbal Industry Association "Herbapol" subjected to the Ministry of Food Industry covered 350 positions. However, their share of sales when compared to pharmacological medicines was minimal, and it equaled barely seven percent of total supplies. Plants of Committee of Small Production had a bigger share. Delivery of 220 positions from the register was done by Association of Producers of Serums and Vaccines subordinated to the Ministry of Health and Social Care. See: Report for the council of workers of Ministry of Health and Social Care about problems of supplying the country with medicines, n.p., n.d. (probably 1965) // AAN, Ministry of Health and Social Care, sign. 19/595. P.31-32. 
and vaccines ${ }^{32}$. The institutions regulated by MPCh(iL) were doing pharmaceutical research and development with a special emphasis on antibiotics, vitamins, and medications against heart diseases. MZiOS had influence over several institutes of the Medical Sciences Department of the Polish Academy of Sciences (Polska Akademia Nauk - PAN) ${ }^{33}$. Moreover, it had influenced over fourteen independent R\&D institutes, finally over ten medical academies in Poland and several others ${ }^{34}$. In the mid-eighties, over 90 thousand doctors and dentists, sixteen thousand pharmacists and almost 180,000 nurses and midwives were employed in Polish healthcare ${ }^{35}$.

Let us focus on institutions subordinated to the minister of the chemical industry. Firstly, they were in more or less direct contact with intelligence. Secondly, their scientific efforts had a relatively quick impact on Polish pharmaceutical industry achievements. The Ministry of the Chemical Industry played the role of intermediary between intelligence and two key R\&D institutions such as the Institute of Pharmacy (Instytut Farmacji - IF) and the Institute of Antibiotics (Instytut Antybiotyków - IA) ${ }^{36}$. Both of these institutions were formed in the fifties. The memoirs of former manager of the Institute of Pharmacy Dr. Wiesław Szelejewski (1982-2007) provide some insight. He implied that both institutes remained in competition ${ }^{37}$. In 1972, they became unified, and the function of manager of the newly formed Institute of Pharmaceutical Industry (Instytut Przemysłu Farmaceutycznego - IPF), subordinated to the minister of chemical industry, was entrusted to the former manager of the IP (since 1965) Dr. Kazimierz Samuła and not to the former manager of IA Prof. Halina Bojarska-Dahlig ${ }^{38}$. According to Szelejewski, the ambitious undertakings of Edward Gierek's administration had rather negative effects on the pharmaceutical trade ${ }^{39}$.

Questions concerning the participation of Polish intelligence in the results of scientific research done by both institutes is important due to the significant influence of these researches on public healthcare in Poland. Many of these were emphasized in the memoirs of Dr. Szelejewski, or can be seen on the current website of the Institute of Biotechnology and Antibiotics (IBA), the successor of IA. In the years 1952-1965, the IF introduced more than 40 technologies of pharmaceutical substances into production, including antibiotics, and the IF workers obtained 132 patents. The total income of the state treasury from the

${ }^{32}$ General justification for collective project of the plan of development of science and technology in the Ministry of Health and Social Care for years 1971-1975 // AAN, Ministry of Health and Social Care, sign. 15/17, n.p., n.d. (probably 1970). P. 2.

33 Especially Institute of Immunology and Experimental Therapy, Center of Experimental and Clinical Medicine, Institute of Pharmacology and Institute of Physiology.

${ }^{34}$ Institute of Medicines, Center of Medical Technology, and Association of Orthopedic Industry "Ortmed." See: General justification for collective project of the plan of development of science and technology in the Ministry of Health and Social Care for years 1971-1975, n.p. [1970] // AAN, Ministry of Health and Social Care, sign. 15/17. P. 2-6; Question of organization and scientific planning in PPR with detailed taking into account of medical science // AAN, Ministry of Health and Social Care, sign. 2/10. P.276-277.

35 Ministry of Health and Social Care - Statistical Bulletin 1985, Warsaw 1986 // AAN, Ministry of Health and Social Care, sign. 19/689, introduction.

36 Specification of organizational units of chemical industry according to administrative division and economic achievements, n.p. 1975 // AAN, Ministerstwo Przemysłu Chemicznego (Ministry of Chemical Industry), sign. 3/3. P. 3.

37 See: 60 lat Instytutu Farmaceutycznego 1952-2012 / eds W. Szelejewski, T. Paszkowska-Reymer. Warsaw, 2012. P. 18.

38 URL: http://www.iba.waw.pl/o_instytucie-historia.html (accessed: 11.08.2020).

3960 lat Instytutu Farmaceutycznego. P. 17-18. 
technologies implemented by the IF in those years was 1,5 billion $\mathrm{zł}$ (after subtracting expenses on the IF of total $175 \mathrm{mln} \mathrm{zf})^{40}$. In 1973, the united IPF showed one of the four highest coefficients of effectiveness out of twenty OBRs subordinated to the MPCH, bringing about $160 \mathrm{mln}$ zł of economic profits (after subtracting investment costs of almost $70 \mathrm{mln}$ $\mathrm{zf})^{41}$. Manager Szelejewski unequivocally estimated that the basic task of R\&D work of IF/ IPF was of the "anti-import" nature ${ }^{42}$. Due to the lack of more advanced research on the IA history it is impossible to one evaluate the scale of this institute's contribution to the development of Polish pharmacy. The IBA's website provides only the information about what kind of substances were developed in that plant since the sixties ${ }^{43}$.

According to the data from the United Nations Economic Commission for Europe in 1969 , Poland was the tenth largest drug manufacturer in the world. The value of production expressed in retail prices amounted to 253 million USD at that time. Such an impressive growth was a response to the needs of the society increasingly troubled by "diseases of civilization" (cardiovascular diseases, cancer), characteristic of highly developed countries. Consumption of drugs per capita in the PPR increased from 1955 to 1980 tenfold. However, the consumption in Poland was still drastically different from such countries as Germany, France, Sweden, the USA, or Japan. The most spectacular increase in production was observed in the field of antibiotics, which in 1956 amounted to about 9 tonnes in Poland, and in 1970 - to over 430 tones. The Polish pharmaceutical industry was one of the most profitable branches of the economy of the PPR due to its excellent export performance. The most important market for Przedsiębiorstwo Przemysłu Farmaceutycznego "Polfa" was the USSR, which constituted at the beginning of the 70s as much as approx. $94 \%$ of total exports to socialist countries ${ }^{44}$.

In the eighties, the Polish pharmaceutical industry comprised twelve factories altogether. They produced anti-infectious agents, antibiotics, hormonal psychotropic, circulatory, anti-inflammatory, analgesic, anticancer medicines, and vitamins. Undoubtedly, the most important company was the Tarchomin Pharmaceutical Plant (TZF), near Warsaw. In the beginning it produced penicillin, barbiturates, procaine, insulin, polocaine, adaline, acetarsol, and hepafort, and in the sixties the assortment increased with antibiotics such as oxytetracycline, erythromycin, neomycin, streptomycin, tetracycline, phenoxymetylpenicillin (penicillin V), viomycin, and others. The TZF owned more than 50 percent of the Polish medicine exports, delivering medicines to dozens of markets in other countries. Among other key producers, there were Warsaw and Cracow Pharmaceutical Plants. Warsaw developed synthesized substances and medicines (for example: hydantoina, phenazoline, antikol) as well as packaging (providing the market with one third of ready-made "Polfa" medicines). Cracow produced vitamin C, B6, antimycobacterial drugs, antibiotics (oxytetracycline), and innovative synthetic medicine bicordin, recognized worldwide ${ }^{45}$.

4060 lat Instytutu Farmaceutycznego. P. 14-15.

${ }^{41}$ Co-efficient of efficiency of work of research units for year 1973 counted according to the principles of directive no. 134 of Ministry of Chemical Industry /// AAN, Ministry of Chemical Industry, sign. 22/69, [lacks page-number].

4260 lat Instytutu Farmaceutycznego. P. 17.

43 Instytut Biotechnologii i Antybiotyków. URL: http://iba.waw.pl/o_instytucie-historia.html (accessed: 11.08.2020).

${ }^{44}$ Kurkowska-Bondarecka K. Historia polskiego przemysłu farmaceutycznego. Warsaw, 1995. P.87, 93-95. Series: Karty z historii polskiego przemysłu chemicznego, vol.3.

${ }^{45}$ For more on other pharma-plants, see: Ibid. P. 75-263. 
Furthermore, the Company of Pharmaceutical Supply "Cefarm," a subordinate to the Ministry of Health and Social Care, was distributing medicines in Poland ${ }^{46}$, while foreign trade was done by the Import-Export Centre of Chemicals "Ciech," which was in turn connected to the Ministry of Chemical Industry ${ }^{47}$.

A very relevant reorganization of pharmaceutical R\&D was carried out in 1981. Former Institute of Antibiotics under new manager Dr. Ing. Edward Żukowski, was split off from a united IPF and transferred to the Department of Progress and Development of Tarchomin Pharmaceutical Plant (TZF) where it remained until 1985 (when it once again became an independent OBR of Biotechnology) ${ }^{48}$. Meanwhile the branch of the former Institute of Pharmacy remained de facto alone as Institute of Pharmaceutical Industry (IPF). It coordinated the government's crucial program concerning medicines, in which it cooperated with the Office of Operational Program "Leki" ("Medicines") 49.

This reorganization is worth noting because the year 1984 is the second time after 1976 when there were numerous tasks assigned to WNT aimed at the secret goal of gaining technologies in the production of antibiotics in Western Europe (for more see in the second part of this article). It should be pointed out that among twelve plants producing and packaging medicines subordinated to the Pharmaceutical Industry Association "Polfa," the main "customer" of intelligence was Tarchomin Pharmaceutical Plant (TZF). Therefore, it was more probable that the temporary merger between the Institute of Antibiotics (IA) with TZF was supposed to improve the intended exchange of information among intelligence (MSW) - branch ministry (MPCh[iL]), science (IA), and industry (TZF). They had a final goal to effectively implement pharmaceutical technologies brought to Poland by secret means. It should be emphasized that the beneficiary of intelligence work in the eighties was also IF/IPF, which profited from WNT's operations: cryptonym "Pathyl" - clandestine acquisition of medicine used in arterial hypertension ${ }^{50}$, and operation "Spiro" - clandestine acquisition of medicine used in therapy of cardiovascular system disorder. The latter was executed in cooperation with USSR intelligence ${ }^{51}$.

Presumably, pharmaceutical products were not featured in the US-Export Control Act of 1949 and in subsequent amendments throughout the fifties, sixties, and seventies ${ }^{52}$. Nonetheless, initially US authorities supervised machines and equipment used in drug

${ }^{46}$ Historia farmacji. P. 245-249.

47 Apart from "Polfa," which was subordinated to the chemical industry, a certain - though much smaller - part for Polish medical care was fulfilled by Herbal Industry Association "Herbapol" (subjected in the seventies to the Ministry of Food Industry) and Association of Producers of Serums and Vaccines "Biomed" (subjected to the Ministry of Health and Social Care). See: Basic questions of pharmacy department, 1973. June 22 // AAN, Ministry of Health and Social Care, sign. 15/15. P. 11.

48 Since 1992, it had been named Institute of Biotechnology and Antibiotics. See: Instytut Biotechnologii i Antybiotyków. URL: http://www.iba.waw.pl/o_instytucie-historia.html (accessed: 11.08.2020).

4960 lat Instytutu Farmaceutycznego. P. 17-18.

${ }^{50}$ Minister of chemical and light industry Edward Grzywa to minister of internal affairs army general Czesław Kiszczak, 1986. July 10 // AIPN, sign. 01824/23. P. 16.

${ }^{51}$ Chief of Division V to the deputy chief of Department I of Ministry of Internal Affairs, Warsaw, 1988. September $26 / /$ AIPN, sign. 01929/36. P. 21.

52 For the detailed content of the so-called industrial lists of dual-use components (especially in category of chemical substances), see: Consolidated Lists of Goods Subject to Embargo for Soviet Bloc and China, published by the British Government in 1954, 1958, 1960-1962, 1964, 1966, 1969, 1972 and 1976. URL: http://evansresearch.org/cocom-lists/ (accessed: 11.08.2020). 
production, for example, counter-current separators for the manufacture of penicillin ${ }^{53}$. The State Department also had some doubts about sharing the technology of vaccination against Polio with the USSR in the fifties. Eventually US authorities decided to cooperate with the political enemy enabling major success of a vaccination program in USSR and Poland ${ }^{54}$.

An integral part of the American Export Administration Act of 1979 was the Commodity Control List worked out by the US Department of Trade, which took into account, among ten thematic groups, also group number 7 entitled "Chemical substances, metalloids, petroleum industry products." However, nothing indicates that among "chemical substances" there were also medicines included ${ }^{55}$. Analysis of products and technologies subjected to trade restrictions in the USA (in Japan and in Europe) at the end of the seventies does not leave any doubts that microelectronics was the most sensitive commodity ${ }^{56}$. It should be stressed that western entrepreneurs, independent from CoCom regulations, were gaining significant profits selling drugs to the socialist countries' markets, and therefore, they protected their formulas refusing to transfer their know-how in the license form. So, apart from the situations in which the PPR could not afford to buy a license because of insufficient funds, those licenses could not be bought due to marketing policy of a certain company, which in turn made the assistance of the intelligence service indispensable in selected areas.

It is noteworthy the WNT only supplemented and not replaced Polish pharmacy. According to the assessment of MZiOS from 1974, the national industry met as much as 85 percent of demand in Polish medicine market ${ }^{57}$. According to the expert's report made in the MPCh in 1974, the "...pharmaceutical industry satisfies its development requests by 95 percent with its own scientific research" 58 . Indeed, in the seventies, "Polfa" bought only a dozen of one hundred and several dozen licenses implemented in the chemical sector ${ }^{59}$. The support of intelligence was not included in those five percent "development" or the fifteen percent "industrial" gap, which were filled with the import of technological thought or ready-made products. Moreover, the secret share, hard to quantify, was specified in official documents as "own" production in the respective category of "own" R\&D output.

Purchasing a license legally did not necessarily solve the problem, and rather caused them given the unfavorable background of the state planned economy in PPR. Some espe-

${ }^{53}$ Łotysz S. Controlling the production and distribution of drugs in communist Poland // Medicina nei Secoli, Arte e Scienza. 2014. Vol. 26, no. 2. P. 547-549.

${ }_{54}$ Oshinsky D. M. Polio. Historia pokonania choroby Heinego-Medina. Warsaw, 2015. P. 420-421.

55 "Memo," Warsaw, 13 April 1988 // AIPN, sign. 02320/21, Vol.1. P. 54-58. The Polish import from the West as well as from other socialistic countries within pharmaceutical sector (in the sense of goods, plants, and licenses), does not seem to have played an important role compared to the share of electrical machines, natural resources (fuels), or other branches of chemistry (plastics, household chemicals, building materials, chemical, and biotechnological solutions for agriculture). The detailed statistics are available: Fallenbuchl Z. M. East-West Technology Transfer: Study of Poland 1971-1980. Paris, 1983. P.9-44.

56 For more on this topic, see: Technology and East-West Trade. Washington, 1979. P. 153-160.

57 Department of Medical Technology and Pharmacy - policy of supplying with medicines and assessment of their quality, n.p. 1974 // AAN, Ministry of Health and Social Care, sign. 19/610. P. 5.

${ }^{58}$ License policy in chemical industry," n.d. (probably 1974) // AAN, Ministry of Chemical Industry, sign. 22/69, [lacks page-number].

59 Among these ten, there were products such as Calcium, Flucinar, Locacortam, Rondomycin, Thenalidin, Toclase, Trasylol, and Vibramycin. See: Basic questions of pharmacy department, 1973. June 22 // AAN, Ministry of Health and Social Care, sign. 15/15. P. 20. 
cially serious problems arose during the launch of the production-line of modern antibiotics in TZF during the seventies. Zbigniew Fallenbuchl describes an unlucky investment and gives a very profound analysis of the east-west trade and technology-transfer prepared in 1983 for the Organization of Economic Cooperation and Development (OECD): "In 1973, the Planning Commission approved of the purchase of the license to produce penicillin $\mathrm{G}$ and some other antibiotics by the pharmaceutical enterprise 'Polfa' in Tarchomin. After a survey of various alternatives, the license was purchased from an American firm Squibb and an arrangement was made with an American engineering firm McKee for technical assistance in the construction of the plant and in the installation of the production lines. The amount of $\$ 5$ million which was paid for the license was expected to be recovered by 1981 from exports of the antibiotics to be produced on its basis. The Planning Commission decided, however, not to include the construction of the Tarchomin plant in the investment plans of the chemical industry for 1976 and 1977, and the R\&D work in connection with the utilization of this license was abandoned in 1976. The construction of the plant was then among the 'priority investments' in the plan for 1978. The construction was, however, delayed for lack of free productive capacity in the construction and the installation enterprises, lack of building materials and various pieces of equipment. It had not been completed by September 1981 when the contractual obligations of the license support and the guarantees on the already delivered machines and equipment were terminated. Completion of the project, which because of a very acute shortage of antibiotics in the country was again classified as important, was shifted to 1982. It became necessary to extend the license for an additional period of 3 years in order to secure a guarantee for the first period of its utilization. Because of reductions in other sectors of the economy there will [from this point Fallanbuchl anticipates. - M. S.], however, be no supply of necessary materials from domestic production and most of them will have to be imported from the advanced countries in the West. It seems that in this case the Planning Commission is responsible for the failure to include the project in the investment plan as soon as it had approved the purchase of the license and [for the failure. - M.S.] to secure for it all necessary complementary machines, equipment and materials. The cause is not technical but systemic"60.

Such accidents, resulting from weaknesses of the planned economy, gave Polish authorities an additional incentive to replace legal means of trade by intelligence along with its capabilities to obtain solutions on the "black market". Thanks to the intelligence's trade channels, valuable foreign currencies could possibly be collected and spent in other crucial areas, in particular by repaying loans to western European creditors ${ }^{61}$. Additionally, the cost of technologies purchased "illegally" was several hundred percent lower than the purchase of official licenses. It is confirmed in many dozens of cable exchanges between the Ministry of Chemical Industry and intelligence. Based on analyzed materials, it is possible to initially note that intelligence focuses mainly on one of around a dozen, though most costly segments of medicine production - i. e. antibiotics, which obviously did not exclude leading selective operations in other key segments, such as vaccines or cardiology. However, even during the most intense periods, its input could not exceed more than twenty percent of solutions implemented by the Polish pharmaceutical industry in the mass production every year.

${ }^{60}$ Fallenbuchl Z.M. East-West Technology Transfer. P. 80.

${ }^{61}$ For more, see: Zloch-Christy I. Debt problems of Eastern Europe. Cambridge, 1987. P. 105-113. 
In the second part of the article, I will analyze intelligence documents on operations aimed at bringing technology of medicine production to Poland. Moreover, I will try to quantify the economic effects of illegal purchases approved by the authorities of the People's Republic of Poland. I will also discuss the assets and modus operandi of the Division of Chemical Scientific and Technical Intelligence. On the example of HIV, I will also present analytical, informational and prognostic functions of the intelligence service of PPR operating in the area of health care.

\section{References}

Bagieński W. Wkład wywiadu gospodarczego w rozwój przemysłowy w dekadzie Edwarda Gierka. Dekada Gierka. Wnioski dla obecnego okresu modernizacji Polski. Warsaw, Uczelnia Vistula, 2011, pp. 57-71.

Bagieński W. Wywiad cywilny Polski Ludowej w latach 1945-1961, t. 1-2. Warsaw, IPN Publ., 2017.

Bergien R. Programmieren mit dem Klassenfeind. Die Stasi, Siemens und der Transfer von EDV-Wissen im Kalten Krieg. Vierteljahreshefte für Zeitgeschichte, 2019, Bd. 67, no 1, pp. 1-30.

Bułhak W. Pion 'N' wywiadu cywilnego PRL. Ewolucja struktur, uwarunkowania organizacyjno-prawne i przykłady operacji tzw. wywiadu nielegalnego w strukturach Ministerstwa Bezpieczeństwa Publicznego, Komitetu ds. Bezpieczeństwa Publicznego i Ministerstwa Spraw Wewnętrznych. Studia nad wywiadem $i$ kontrwywiadem Polski w XX wieku, t. 1. Szczecin, IPN Publ., 2012, pp. 607-682.

Cain F. Computers and the Cold War: United States Restrictions on the Export of Computers to the Soviet Union and Communist China. Journal of Contemporary History, 2005, vol. 40, no. 1, pp. 131-147.

Chertoprud S. V. Scientific and technical intelligence from Lenin to Gorbachev. Moscow, Olma Press, 2002, 444 p. (In Russian)

Fallenbuchl Z. M. East-West Technology Transfer: Study of Poland 1971-1980. Paris, OECD Publications and Information Center, 1983, 199 p.

Hallam S. Biotechnology and Society. An introduction. Chicago, London, University of Chicago Press, 2016, $397 \mathrm{p}$.

Hobsbawm E. Wiek skrajności. Spojrzenie na Krótkie Dwudzieste Stulecie. Warsaw, Politeja historia, 1999, $572 \mathrm{p}$.

Kamieński Ł. Technologia i wojna przyszłości. Wokół nuklearnej i informacyjnej rewolucji w sprawach wojskowych. Krakow, Wydawnictwo UJ, 2009, 411 p.

Kurkowska-Bondarecka K. Historia polskiego przemysłu farmaceutycznego, Warsaw, Stowarzyszenie Inżynierów i Techników Przemysłu Chemicznego, 1995, 324 p. Series: Karty z historii polskiego przemysłu chemicznego, vol. 3 .

Landes D.S. Bogactwo i nędza narodów. Dlaczego jedni sa tak bogaci, a inni tak ubodzy [The Wealth and Poverty of Nations]. Warsaw, Muza, 2005, 732 p.

Łotysz S. Controlling the production and distribution of drugs in communist Poland. Medicina nei Secoli, Arte e Scienza, 2014, vol.26, no. 2, pp. 519-556.

Macrakis K. Seduced by Secrets. Inside the Stasi's Spy-Tech World. Cambridge, Cambridge University Press, $2008,370 \mathrm{p}$.

Maddrell P. Spying on Science: Western Intelligence in Divided Germany 1945-1961. Oxford, Oxford University Press, 2006, 330 p.

Mastanduno M. Economic Containment: CoCom and the Politics of East-West Trade. Ithaca, New York, Cornell University Press, 1992, 353 p.

Mukherjee S. Cesarz Wszech Chorób. Biografia raka. Gorlice, Czarne, 2013, 616 p.

Oshinsky D. M. Polio. Historia pokonania choroby Heinego-Medina. Warsaw, Prószyński i S-ka, 2015, 552 p.

Paczkowski A. Rezydentura wywiadu MSW w Ministerstwie Przemysłu Maszynowego (1971-1983). "Budujemy socjalizm...." Materiały pokonferencyjne. Wroclaw, IPN, 2010, pp. 47-60.

Pawlikowicz L. Tajny Front Zimnej Wojny. Uciekinierzy z polskich służb specjalnych 1956-1964. Warsaw, Oficyna wydawnicza rytm, 2004, $416 \mathrm{p}$.

Richelson J.T. The Wizards of Langley, Inside CIA's Directorate of Science and Technology. Boulder, Basic Books, 2001, 386 p. 
Selvage D., Nehring Ch. Die AIDS-Verschwörung: Das Ministerium für Staatssicherheit und die AIDSDesinformationskampagne des KGB. BF informiert, 2014, no. 33, pp. 21-25.

Siemiątkowski Z. Wywiad a władza. Wywiad cywilny w systemie sprawowania władzy politycznej PRL. Warsaw, Aspra, 2009, 420 p.

Sikora M. Intelligence-interchange in the area of Science and Technology between Poland and Soviet Union 1986-1990. Technology in Times of Transition. 41 ICOHTEC Symposium 2014. Brasov, 2014, pp.97106.

Sikora M. Terapia czarnorynkowa. Pomoc wywiadu MSW dla branży farmaceutycznej i biotechnologicznej w PRL 1960-1990. Kwartalnik Historii Nauki i Techniki PAN, 2017, t. 4, pp.65-104.

Sikora M. The only globally successful "company" in Communist Poland? Scientific-technical intelligence and its role in technology transfer 1971-1989. ICON Journal of the International Committee for the History of Technology, 2020, Vol. 25, no. 1, pp. 12-38.

Sikora M. Wirtschaftliche Innovation durch Spionage. Forschung, Entwicklung und der Geheimdienst in der Volksrepublik Polen 1970-1990. Jahrbücher für Geschichte Osteuropas, 2014, Bd. 62, Nr. 4, S. $564-$ 590.

Tubiana M. Nowotwory. Warsaw, [s. n.], 1995, 136 p.

Zacharski M. Nazywam się Zacharski. Marian Zacharski. Wbrew regułom. Poznan, Zysk i S-ka, 2009, 528 p. Zloch-Christy I. Debt problems of Eastern Europe. Cambridge, Cambridge University Press, 1987, 220 p.

Статья поступила в редакцию 14 мая 2020 г. Рекомендована в печать 9 сентября 2020 г.

Received: May 14, 2020 Accepted: September 9, 2020 